\title{
Analisis Inflasi dan Impor Indonesia
}

\author{
Dewi Mahrani Rangkuty ${ }^{*}$, Lia Nazliana Nasution ${ }^{2}$ \\ ${ }^{1,2}$ Fakultas Sosial Sains Universitas Pembangunan Panca Budi, Jl. Gatot Subroto No.km 4, \\ Simpang Tj., Medan Sunggal, Kota Medan,Sumatera Utara 20122 \\ *e-mail : dewimahrani@dosen.pancabudi.ac.id
}

\begin{abstract}
ABSTRAK
Indonesia merupakan negara yang menganut sistem perekonomian terbuka. Semenjak dari masa kemerdekaan sampai dengan sekarang masih terus menjadi bagian dan atau pelaku di pasar internasional. Kecenderungan mengeskpor untuk meningkatkan pendapatan negara diikuti pula dengan mengimpor barang/jasa modal dan jenis barang/jasa ekonomi lainnya yang dikonsumsi oleh penduduk domestik. Tujuan penelitian ini adalah untuk menganalisis data laju pertumbuhan inflasi dan impor Indonesia dengan time series mulai dari tahun 1991-2017. Hasil penelitian dengan metode analisis VAR (vector autoregression) didapatkan bahwa Inflasi dan impor tidak berkaitan erat dan tidak saling mempengaruhi berdasarkan kurun waktu penelitian ini karena tidak memiliki hubungan sebab akibat. Inflasi periode yang lalu tidak mempengaruhi secara signifikan terhadap impor Indonesia. Peningkatan impor berpengaruh positif terhadap inflasi berdasarkan persamaan VAR. Dan antara inflasi dan impor terdapat hubungan stabilitas keseimbangan jangka panjang dan pergerakan dalam jangka panjang. Sementara dalam jangka pendek kedua variabel inflasi dan impor saling menyesuaikan untuk mencapai keseimbangan jangka panjang. Hal yang dapat direkomendasikan kepada pemerintah yakni Bank Indonesia diharapkan dapat tetap menjaga laju inflasi terkait kestabilan nilai rupiah baik di dalam maupun luar negeri sehingga dapat menekan kuota impor yang dapat mengurangi kecenderungan konsumsi terhadap barang/jasa impor oleh penduduk domestik.
\end{abstract}

Kata kunci: inflasi dan impor 


\title{
Analysis of Indonesian Inflation and Imports
}

\begin{abstract}
Indonesia is a country has open economic system. During independence until now still a part of and or agent for international market. Trends of Indonesia's export for increasing national income that followed import capital goods/service and kinds of other economic goods/service had consumed by Indonesia societies. This research has aimed for analyze datum of growth for inflation and import of Indonesia with time series 1990-2017. The result of VAR analysis method has inflation and import hasn't causality and hasn't influence by the period of this research. The inflation of past period hasn't influence and significantly to Indonesia's import. Increasing of import as positive to inflation by equation of VAR. And between inflation anad import has equilibrium stability relationship for long term and long term fluctuation. Then, for short term of variables for inflation and import mutually adjusted for long term equilibrium. The recommendation for Indonesia's government is Central Bank still keep in inflation rate for rupiah stability value for in domestic and or in international market so that could be pushed import quota for consume preference for import goods/service by domestic societies.
\end{abstract}

Keywords : Inflation and Import 


\section{PENDAHULUAN}

Inflasi merupakan suatu keadaan di mana terjadi kenaikan harga-harga secara tajam (absolute) yang berlangsung terus menerus dalam jangka waktu cukup lama. Seirama dengan kenaikan harga-harga tersebut, nilai uang turun secara tajam pula sebanding dengan kenaikan harga-harga tersebut, nilai uang turun secara tajam pula sebanding dengan kenaikan harga-harga tersebut. Sedangkan menurut Keynes inflasi adalah kenaikan dalam tingkat harga rata-rata, harga adalah dimana mempertukarkan uang dengan barang atau jasa (Mankiw, 2003).

Inflasi yang terus berlanjut apalagi sampai melampaui angka dua digit dapat berpengaruh pada distribusi pendapatan dan alokasi faktor produksi nasional. Selain itu prospek pembangunan jangka panjang merupakan bagian penting dari kegiatan ekonomi suatu negara. Inflasi akan terus bertambah cepat apabila tidak diatasi. Inflasi yang bertambah serius akan mengurangi investasi yang produktif, mengurangi ekspor dan mengurangi impor. Kecenderungan ini akan memperlambat pertumbuhan perekonomian. Inflasi juga menyebabkan harga barang impor menjadi lebih murah daripada barang yang dihasilkan dalam negeri. Maka pada umumnya inflasi akan menyebabkan impor berkembang lebih cepat dibandingkan dengan ekspor (Sukirno, 2002).

Penyebab terjadinya inflasi yaitu pertama, inflasi tarikan permintaan (demand pull inflation) terjadi dikarenakan adanya permintaan total yang berlebihan dan biasanya disebabkan oleh meningkatnya likuiditas di pasar dan mengakibatkan permintaan yang tinggi sehingga memicu perubahan pada tingkat harga. Bertambahnya volume alat tukar atau likuiditas yang terkait dengan permintaan terhadap barang dan jasa mengakibatkan naiknya permintaan terhadap faktor-faktor produksi tersebut. Dengan kenaikan permintaan terhadap faktor produksi itu yang menyebabkan peningkatan dan kenaikan faktor produksi. Jadi, inflasi ini disebabkan adanya peningkatan dalam permintaan total saat perekonomian bersangkutan dalam keadaan full employment dimana biasanya lebih disebabkan oleh rangsangan volume likuiditas di pasar yang berlebihan. Tingginya likuiditas di pasar juga dipengaruhi oleh banyak faktor selain tentunya kemampuan bank sentral dalam mengatur jumlah uang yang beredar, kebijakan suku bunga bank sentral, sampai dengan aksi spekulasi yang terjadi di sektor industri keuangan. Kedua, inflasi desakan biaya (cost push inflation) dikarenakan adanya produksi yang langka dan/atau juga termasuk juga kelangkaan distribusi, walaupun secara umum permintaan tidak ada perubahan yang meningkat secara signifikan. Tidak lancarnya aliran distribusi ini atau turunnya produksi yang tersedia dari rata-rata permintaan normal dapat menimbulkan kenaikan harga sesuai dengan berlakunya hukum permintaan penawaran, bisa juga disebabkan karena terbentuknya posisi nilai keekonomian yang baru dalam produk tersebut akibat pola atau skala distribusi yang baru. Berkurangnya produksi tersebut bisa terjadi akibat berbagai hal seperti adanya masalah teknis di sumber produksi (pabrik, perkebunan, dll), bencana alam, iklim dan cuaca, atau langkanya bahan baku dalam menghasilkan produksi tersebut, aksi spekulasi (penimbunan) dan lain-lain sehingga memicu kelangkaan produksi yang terkait tersebut di pasaran. Begitu juga hal yang sama dapat terjadi pada distribusi, dimana dalam hal ini faktor infrastruktur memainkan peranan yang sangat penting. 


\section{Published December 2018}

\section{EKONOMIKAWAN : Jurnal Ilmu Ekonomi dan Studi Pembangunan}

ISSN : 1693-7600 (Print), ISSN : 2598-0157 (Online), http://jurnal.umsu.ac.id/index.php/ekawan

Inflasi juga dapat disebabkan dari kenaikan harga barang-barang impor. Inflasi ini terjadi apabila barang-barang impor mengalami kenaikan harga yang memiliki peranan penting dalam kegiatan pengeluaran perusahaan-perusahaan. Inflasi dari impor ini juga dapat menimbulkan stagflasi seperti yang terjadi pasca krisis ekonomi, stagflasi menggambarkan dimana kegiatan ekonomi semakin menurun, pengangguran semakin tinggi dan pada waktu yang sama proses kenaikan harga-harga semakin tinggi (Sukirno, 2004).

Inflasi juga dapat dibagi berdasarkan besarnya cakupan pengaruh terhadap harga. Jika harga naik yang disebabkan oleh satu atau dua barang tertentu, inflasi itu disebut inflasi tertutup (closed inflation). Namun, jika kenaikan harga terjadi pada semua barang secara umum, maka inflasi itu disebut sebagai inflasi terbuka (open inflation). Sedangkan apabila serangan inflasi demikian hebatnya sehingga setiap saat harga-harga terus berubah dan meningkat sehingga orang tidak dapat menahan uang lebih lama disebabkan nilai uang terus merosot disebut inflasi yang tidak terkendali (hyperinflation).

Bank Sentral memiliki peranan yang sangat penting dalam mengendalikan inflasi. Bank sentral suatu negara pada umumnya berusaha mengendalikan tingkat inflasi pada tingkat yang wajar. Beberapa bank sentral bahkan memiliki tanggung jawab dan wewenang yang independen dalam artian bahwa kebijakannya tidak boleh diintervensi oleh pihak luar bank sentral termasuk pemerintah. Hal ini dikarenakan sejumlah studi menunjukkan bahwa bank sentral yang kurang independen, salah satunya disebabkan intervensi pemerintah yang bertujuan menggunakan kebijakan moneter untuk mendorong perekonomian, justru akan mendorong tingkat inflasi ke arah yang lebih tinggi.

Bank sentral pada umumnya mengendalikan peredaran uang dan/atau tingkat suku bunga sebagai instrumen dalam mengendalikan tingkat harga. Selain itu, bank sentral juga memiliki kewajiban mengendalikan nilai tukar mata uang dalam negeri. Hal ini dikarenakan nilai sebuah mata uang dapat bersifat internal (ditentukan oleh tingkat inflasi) maupun eksternal (kurs). Saat ini pola inflation targeting banyak diterapkan oleh bank sentral di seluruh dunia, termasuk juga Bank Indonesia.

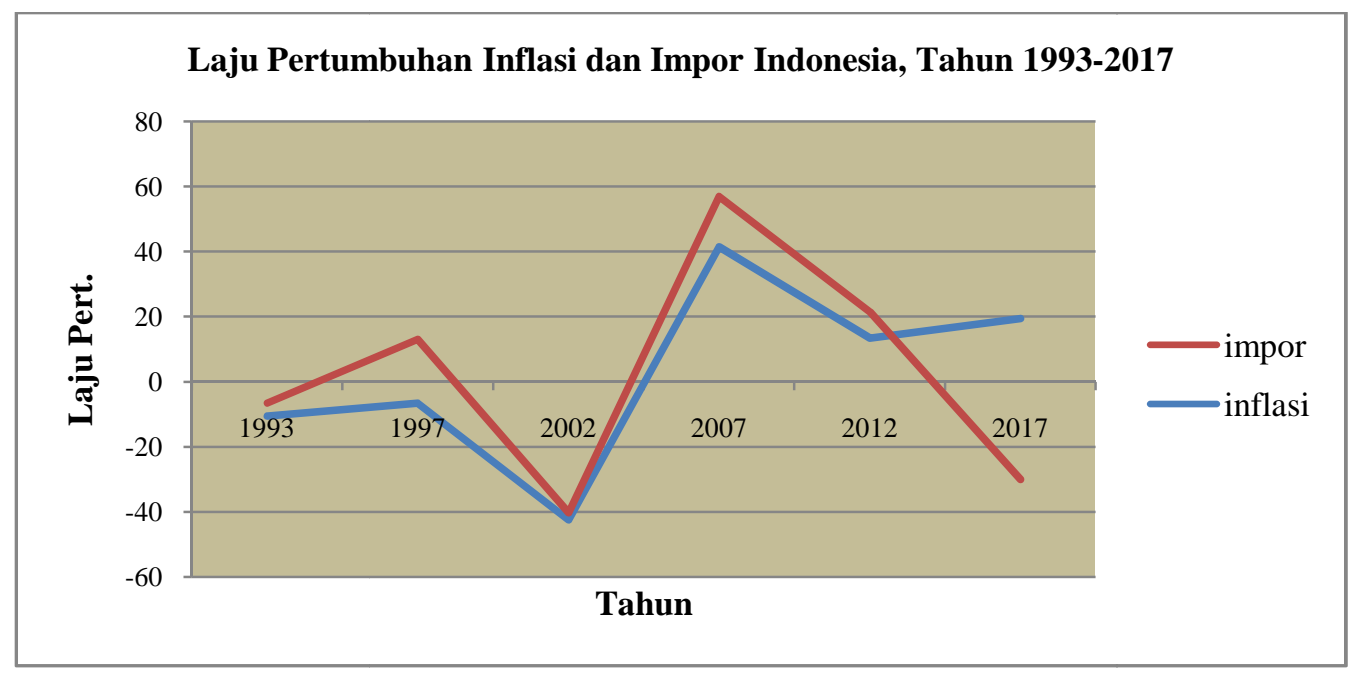

Gambar 1

Laju Pertumbuhan Inflasi dan Impor Indonesia, Tahun 1993-2017 
Impor dapat diartikan sebagai pembelian barang dan jasa dari luar negeri ke dalam negeri dengan perjanjian kerjasama antara 2 negara atau lebih. Impor juga bisa dikatakan sebagai perdagangan dengan cara memasukkan barang dari luar negeri ke wilayah Indonesia dengan memenuhi ketentuan yang berlaku (Hutabarat, 1996).

Impor ditentukan oleh kesanggupan atau kemampuan untuk menghasilkan barangbarang yang bersaing dengan bantuan luar negeri. Ini artintya nilai impor tergantung dari pendapatan nasional negara tersebut. Makin tinggi pendapatan nasional, makin rendah dalam menghasilkan barang-barang tersebut, dan impor pun semakin tinggi. Sebagai akibatnya banyak kebocoran dalam pendapatan nasional.

Perubahan nilai impor di Indonesia juga dipengaruhi oleh berbagai situasi dan kondisi sosial politik, pertahanan dan keamanan, inflasi, kurs valuta asing serta tingkat pendapatan dalam negeri yang disebabkan dari sektor-sektor yang dapat memberikan pemasukan selain perdagangan internaisonal. Besarnya nilai impor Indonesia antara lain ditentukan oleh kemampuan Indonesia dalam mengolah dan memanfaatkan sumber yang ada dan juga tingginya permintaan impor dalam negeri.

Berdasarkan Gambar 1 pada tahun 2007 laju pertumbuhan inflasi adalah yang tertinggi selama kurun waktu penelitian yakni sebesar 41,54 persen sedangkan pada tahun 2002 adalah laju pertumbuhan terendah yakni sebesar negatif 42,37 persen. Dan untuk laju pertumbuhan impor tertinggi adalah pada tahun 1997 yakni sebesar 19,46 persen. Sedangkan laju pertumbuhan terendah yakni pada tahun 2017 sebesar negatif 49,54. Fluktuasi angka ini disebabkan karena kondisi harga barang dan jasa di pasar dalam negeri selama kurun waktu penelitian dan volume permintaan barang dan/atau jasa yang diimpor dari luar negeri ke Indonesia.

\section{METODE}

Penelitian ini mengkaji analisis inflasi dan impor Indonesia dengan time series dari tahun 1991-2017. Data yang digunakan dalam penelitian ini adalah data sekunder yang diperoleh dari Bank Dunia (world bank), buku, jurnal, internet, penelitian terdahulu, catatan lain dan sumber lainnya yang berhubungan dengan masalah penelitian.

Permasalahan dalam studi ini akan dianalisis dengan memakai Vector Autoregression. Secara sederhana VAR menggambarkan hubungan yang saling menyebabkan (kausalitas) antar variabel dalam sistem, dengan menambahkan intersep.

1. Uji Stasioneritas

Data ekonomi time series umumnya bersifat stokastik atau memiliki tren yang tidak stasioner, artinya data tersebut memiliki akar unit. Untuk dapat mengestimasi suatu model penggunaan data tersebut langkah pertama yang harus dilakukan adalah pengujian stasioneritas data atau dikenal unit root test (Gujarati, 2003).

2. Pemilihan Lag Optimum

Penentuan jumlah lag (ordo) yang akan digunakan dalam model VAR dapat ditentukan berdasarkan kriteria Akaike Information Criterion (AIC) dan Schwarz Information Criterion (SC). Lag yang akan dipilih dalam penelitian ini adalah model dengan nilai AIC yang paling kecil. Penentuan lag optimum dilakukan terlebih dahulu sebelum memulai tahap uji kointegrasi. 


\section{Published December 2018}

EKONOMIKAWAN : Jurnal IImu Ekonomi dan Studi Pembangunan

ISSN : 1693-7600 (Print), ISSN : 2598-0157 (Online), http://jurnal.umsu.ac.Id/index.php/ekawan

\section{Uji Kointegrasi}

Jika fenomena stasioneritas berada pada tingkat first difference atau I(1), maka perlu dilakukan pengujian untuk melihat kemungkinan terjadinya kointegrasi. Konsep kointegrasi pada dasarnya untuk melihat keseimbangan jangka panjang diantara variabel-variabel yang diobservasi. Terkadang suatu data yang secara individu tidak stasioner, namun ketika dihubungkan secara linear data tersebut menjadi stasioner. Hal ini yang kemudian disebut bahwa data tersebut terkointegrasi. Apabila satu set variabel benar-benar terkointegrasi, maka harus dapat dideteksi implied restriksi atau unrestriksi VAR (Green, 2000).

4. Uji Kausalitas (Granger Causality test)

Uji kausalitas dilakukan untuk mengetahui apakah suatu variabel endogen dapat diperlakukan sebagai variabel eksogen. Hal ini bermula dari ketidaktahuan keterpengaruhan antar variabel. Jika ada 2 variabel y dan $\mathrm{z}$, maka apakah y menyebabkan $\mathrm{z}$ atau $\mathrm{z}$ menyebabkan $\mathrm{y}$ atau berlaku keduanya atau tidak ada hubungan keduanya. Variabel y menyebabkan variabel $\mathrm{z}$ artinya berapa banyak nilai $\mathrm{z}$ pada periode sekarang dapat dijelaskan oleh nilai z pada periode sebelumnya dan nilai y pada periode sebelumnya. Kekuatan prediksi (predictive power) dari informasi sebelumnya dapat menunjukkan adanya hubungan kausalitas antara y dan z dalam jangka waktu lama (Basuki dan Prawoto, 2016).

5. Fungsi Impulse Response VAR

Estimasi terhadap fungsi impulse response dilakukan untuk memeriksa respon kejutan (shock) variabel inovasi terhadap variabel-variabel lainnya. Estimasi menggunakan asumsi masing-masing variabel inovasi tidak berkorelasi satu sama lain sehingga penelusuran pengaruh suatu kejutan dapat bersifat langsung.

6. Variance Decomposition

Variance decomposition mendekomposisi variasi satu variabel endogen ke dalam komponen kejutan variabel-variabel endogen yang lain dalam sistem VAR. Dekomposisi varian ini menjelaskan proporsi pergerakan suatu series akibat kejutan variabel itu sendiri dibandingkan dnegan kejutan variabel lain. Jika kejutan ezt tidak mampu menjelaskan forecast error variance variabel yt maka dapat dikatakan bahwa variabel yt adalah eksogen (Enders, 2004). Kondisi ini variabel yt akan independen terhadap kejutan $\varepsilon z t$ dan variabel zt. Sebaliknya, jika kejutan ezt mampu menjelaskan forecast error variance variabel yt berarti variabel yt merupakan variabel endogen.

\section{HASIL DAN PEMBAHASAN}

\section{Uji Stasioneritas}

Uji stasioner dapat dilakukan dengan metode akar unit. Uji akar unit dengan augmented dicky-fuller (ADF) jika nilai absolute statistic t lebih kecil dari nilai kritis pada tabel MacKinnon pada berbagai tingkat kepercayaan (1\%, 5\%, 10\%) maka mengindikasikan data tidak stasioner. Di samping itu dapat pula dilihat pada nilai Prob. yang lebih besar dari 0,05 yang juga mengindikasikan data tidak stasioner (Winarno, 2007). Sebaliknya jika nilai ADF lebih besar dari nilai kritis berbagai tingkat kepercayaan $(1 \%, 5 \%, 10 \%)$ maka tidak terdapat akar unit atau data stasioner. 
Published December 2018

EKONOMIKAWAN : Jurnal Ilmu Ekonomi dan Studi Pembangunan

ISSN : 1693-7600 (Print), ISSN : 2598-0157 (Online), http://jurnal.umsu.ac.ld/index.php/ekawan

Tabel 1

Hasil Uji Akar Unit ADF

\begin{tabular}{|l|l|c|c|c|}
\hline Variabel & \multicolumn{1}{|c|}{ Unit Root } & ADF test statistic & Prob. & Keterangan \\
\hline \multirow{3}{*}{ Impor } & Level & -4.130729 & 0.0037 & Stasioner \\
\cline { 2 - 4 } & $1^{\text {st }}$ difference & -7.080410 & 0.0000 & \\
\cline { 2 - 4 } & $2^{\text {nd }}$ difference & -3.725608 & 0.0131 & \\
\hline \multirow{3}{*}{ Inflasi } & Level & -7.833910 & 0.0000 & \multirow{2}{*}{ Stasioner } \\
\cline { 2 - 4 } & $1^{\text {st }}$ difference & -3.086268 & 0.0440 & \\
\cline { 2 - 4 } & $2^{\text {nd }}$ difference & -9.057083 & 0.0000 & \\
\hline
\end{tabular}

Sumber: data diolah, Eviews v.9, 2018.

Pada tabel di atas, dapat dijelaskan bahwa nilai Prob. dari ADF test pada variabel impor $<0,05$ artinya sudah stasioner baik pada level, $1^{\text {st }}$ difference maupun $2^{\text {nd }}$ difference. Demikian juga pada variabel inflasi yang sudah stasioner pada level, $1^{\text {st }}$ difference maupun $2^{\text {nd }}$ difference yang nilai Prob. dari ADF test $<0,05$.

\section{Pemilihan Lag Optimum}

Pendekatan VAR sangat sensitif terhadap jumlah lag data yang digunakan, oleh karenanya perlu ditetapkan panjang lag yang optimal. Penentuan panjang lag tersebut dimanfaatkan untuk mengetahui lamanya periode ketepengaruhan terhadap suatu variabel endogen dengan pada waktu-waktu yang lalu maupun terhadap variabel endogen lainnya. Penentuan panjang lag dapat dilihat dari nilai-nilai likelihood ratio (LR), final prediction error (FPE), akaike information criterion (AIC) dan schwarz information (SC). Nilai-nilai dapat dilihat dari Tabel berikut untuk uji panjang lag optimal.

Tabel 2

Hasil Uji Panjang Lag Optimum

\begin{tabular}{|c|c|c|c|c|c|c|}
\hline Lag & LogL & LR & FPE & AIC & SC & HQ \\
\hline 0 & -250.2932 & NA* & $4633279 . *$ & $21.02443 *$ & $21.12260 *$ & $21.05048^{*}$ \\
\hline 1 & -247.7160 & 4.510012 & 5229774. & 21.14300 & 21.43752 & 21.22114 \\
\hline 2 & -246.9654 & 1.188457 & 6923369. & 21.41379 & 21.90464 & 21.54401 \\
\hline 3 & -244.9898 & 2.798788 & 8382129. & 21.58249 & 22.26968 & 21.76480 \\
\hline
\end{tabular}

*indicated lag order selected by the criterion

LR: sequential modified LR test statistic (each test at 5\% level)

FPE: final prediction error

AIC: akaike information criterion

SC: schwarz information criterion

HQ: hannan-quinn information criterion

Sumber: data diolah, Eviews v.9 (2018)

Dari tabel di atas, nilai lag terdapat pada lag 0, dimana pada lag ini terhimpun nilai terendah bagi final prediction error (FPE), akaike information criterion (AIC), schwarz information (SC) dan hannan-quinn information criterion (HQ) titik terendah terdapat pada lag 0 . Oleh karenanya panjang lag optimumnya berada pada lag 0 . 


\section{Published December 2018}

\section{EKONOMIKAWAN : Jurnal IImu Ekonomi dan Studi Pembangunan}

ISSN : 1693-7600 (Print), ISSN : 2598-0157 (Online), http://jurnal.umsu.ac.id/index.php/ekawan

\section{Uji Kointegrasi}

Uji kointegrasi dilakukan untuk mengetahui apakah akan terjadi keseimbangan dalam jangka panjang, yaitu terdapat kesamaan pergerakan dan stabilitas hubungan diantara variabel-variabel dalam penelitian ini atau tidak. Dalam penelitian ini uji kointegrasi dilakukan dengan menggunakan metode Johansen' Cointegration test. Berikut Tabel hasil uji kointegrasi.

Tabel 3

Hasil Uji Kointegrasi

\begin{tabular}{|c|c|c|c|}
\hline Trace statistic & $>$ & Critical value & Prob. \\
\hline 23.79133 & & 15.49471 & 0.0023 \\
\hline Max-Eigen statistic & $>$ & Critical value & Prob. \\
\hline 17.73894 & & 14.26460 & 0.0136 \\
\hline
\end{tabular}

Sumber: data diolah, Eviews v.9, 2018.

Berdasarkan tabel di atas, dapat dijelaskan bahwa nilai trace statistic dan max-eigen statistic pada $\mathrm{r}=0$ lebih besar dari critical value dengan tingkat kepercayaan $5 \%$. Berdasarkan analisis ekonometrik di atas dapat dijelaskan bahwa diantara inflasi dan impor dalam penelitian terdapat kointegrasi pada tingkat signifikansi 5\%. Dengan demikian, dari hasil uji kointegrasi mengindikasikan bahwa di antara pergerakan inflasi dan impor memiliki hubungan stabilitas atau keseimbangan dan kesamaan pergerakan dalam jangka panjang.

\section{Uji Kausalitas (Granger Causality test)}

Uji kausalitas Granger antar variabel penelitian dimaksud untuk mengetahui hubungan kausalitas antara variabel (Nachrowi, 2006). Dari Tabel berikut dapat dilihat hasil uji kausalitas Granger dalam penelitian ini.

Tabel 4

Hasil Uji Kausalitas Granger Causality test

\begin{tabular}{|c|c|c|c|}
\hline Null hypothesis: & Obs & F-statistic & Prob. \\
\hline $\begin{array}{c}\text { INFLASI does not Granger Cause } \\
\text { IMPOR }\end{array}$ & 25 & 0.13362 & 0.8757 \\
\hline $\begin{array}{c}\text { IMPOR does not Granger Cause } \\
\text { INFLASI }\end{array}$ & & 0.10776 & 0.8984 \\
\hline
\end{tabular}

Sumber : data diolah, Eviews v.9 (2018)

Pada tabel di atas kedua variabel yakni inflasi dan impor tidak memiliki hubungan timbal balik atau tidak memiliki hubungan dua arah signifikan pada level 5\% yakni nilai Prob. > 0,05 pada lag 0. Artinya bahwa inflasi periode yang lalu tidak mempengaruhi secara signifikan terhadap impor Indonesia.

Equation VAR:

$\mathrm{IMPOR}=\mathrm{C}(1) * \operatorname{IMPOR}(-1)+\mathrm{C}(2) * \operatorname{IMPOR}(-2)+\mathrm{C}(3) * \operatorname{INFLASI}(-1)+\mathrm{C}(4) * \mathrm{INFLASI}(-$ 2) $+\mathrm{C}(5)$

INFLASI $=\mathrm{C}(6) * \operatorname{IMPOR}(-1)+\mathrm{C}(7) * \operatorname{IMPOR}(-2)+\mathrm{C}(8) * \operatorname{INFLASI}(-1)+\mathrm{C}(9) * \operatorname{INFLASI}(-$ 2) $+\mathrm{C}(10)$ 
EKONOMIKAWAN : Jurnal Ilmu Ekonomi dan Studi Pembangunan

ISSN : 1693-7600 (Print), ISSN : 2598-0157 (Online), http://jurnal.umsu.ac.Id/index.php/ekawan

\section{Fungsi Impulse Response VAR}

Estimasi terhadap fungsi impulse response dilakukan untuk memeriksa respon kejutan (shock) variabel inovasi terhadap variabel-variabel lainnya. Estimasi menggunakan asumsi masing-masing variabel inovasi tidak berkorelasi satu sama lain sehingga penelusuran pengaruh suatu kejutan dapat bersifat langsung.

Gambar impulse response akan menunjukkan respon suatu variabel akibat kejutan variabel lainnya sampai dengan beberapa periode setelah terjadi shock. Jika gambar impulse response menunjukkan pergerakan yang semakin mendekati titik keseimbangan (convergence) atau kembali ke keseimbangan sebelumnya bermakna respon atau variabel akibat suatu kejutan main lama akan menghilang sehingga kejutan tersebut tidak meninggalkan pengaruh permanen terhadap variabel tersebut (Basuki dan Prawoto, 2016).

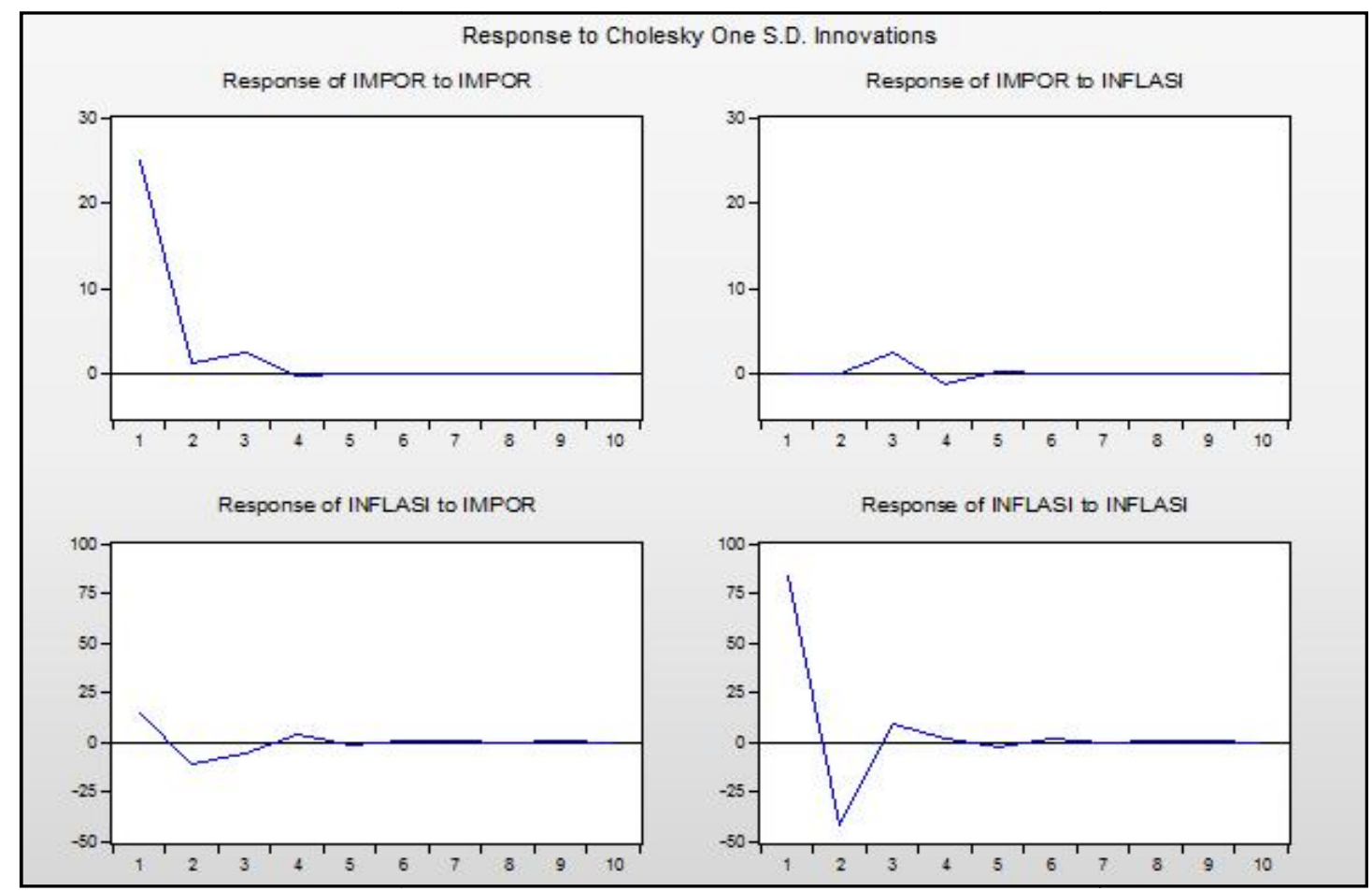

Sumber: data diolah, Eviews v.9 (2018)

Gambar 2

Impulse Response (IR) Inflasi terhadap Impor Indonesia

Pada Gambar di atas diperlihatkan IR impor terhadap impor, impor terhadap inflasi, response inflasi terhadap impor, response inflasi terhadap inflasi. Pada Gambar Response to Cholesky One S.d. innovation terlihat respon impor terhadap impor, impor terhadap inflasi, inflasi terhadap impor dan inflasi terhadap inflasi memiliki pergerakan yang sama hampir di setiap periode data penelitian yakni mendekati garis 0 (nol). 


\section{Published December 2018}

\section{EKONOMIKAWAN : Jurnal Ilmu Ekonomi dan Studi Pembangunan}

ISSN : 1693-7600 (Print), ISSN : 2598-0157 (Online), http://jurnal.umsu.ac.id/index.php/ekawan

\section{Variance Decomposition}

Setelah dianalisis terhadap perilaku dinamis model melalui impulse response function, maka selanjutnya akan dilihat karakteristik model melalui variance decomposition. Hasilnya dapat dilihat pada Tabel berikut dimana fluktuasi different impor dipengaruhi inflasi. Pada periode kedua differen impor tertinggi 99,99 persen terus menurun sampai periode ke sepuluh menjadi 98,75 persen. Sebaliknya pengaruh inflasi terhadap impor mengalami peningkatan secara berlawanan mulai dari 0,00 persen pada periode kedua sampai dengan 1,25 persen pada periode ke sepuluh.

Tabel 6

Hasil Variance Decomposition

Variance Decomposition of IMPOR:

Perio

\begin{tabular}{cccc}
$\mathrm{d}$ & S.E. & IMPOR & INFLASI \\
\hline \hline 1 & 24.95817 & 100.0000 & 0.000000 \\
2 & 24.99206 & 99.99974 & 0.000257 \\
3 & 25.25149 & 98.98016 & 1.019842 \\
4 & 25.27773 & 98.77577 & 1.224230 \\
5 & 25.28122 & 98.74857 & 1.251428 \\
6 & 25.28149 & 98.74845 & 1.251553 \\
7 & 25.28160 & 98.74803 & 1.251968 \\
8 & 25.28165 & 98.74775 & 1.252252 \\
9 & 25.28165 & 98.74769 & 1.252305 \\
10 & 25.28166 & 98.74769 & 1.252308 \\
\hline \hline
\end{tabular}

Variance Decomposition of INFLASI:

Perio

\begin{tabular}{cccc}
$\mathrm{d}$ & S.E. & IMPOR & INFLASI \\
\hline \hline 1 & 84.37964 & 2.744912 & 97.25509 \\
2 & 94.81608 & 3.451675 & 96.54833 \\
3 & 95.44324 & 3.851061 & 96.14894 \\
4 & 95.53228 & 4.011029 & 95.98897 \\
5 & 95.59331 & 4.049426 & 95.95057 \\
6 & 95.60743 & 4.050545 & 95.94945 \\
7 & 95.60898 & 4.050432 & 95.94957 \\
8 & 95.60908 & 4.050589 & 95.94941 \\
9 & 95.60913 & 4.050645 & 95.94936 \\
10 & 95.60915 & 4.050651 & 95.94935 \\
\hline \hline
\end{tabular}

Cholesky Ordering: IMPOR INFLASI

Antara variabel inflasi dan impor terdapat hubungan stabilitas keseimbangan jangka panjang dan pergerakan dalam jangka panjang, sementara dalam jangka pendek inflasi dan impor saling menyesuaikan untuk mencapai keseimbangan jangka panjang. 
Published December 2018

EKONOMIKAWAN : Jurnal IImu Ekonomi dan Studi Pembangunan

ISSN : 1693-7600 (Print), ISSN : 2598-0157 (Online), http://jurnal.umsu.ac.Id/index.php/ekawan

\section{SIMPULAN}

Inflasi dan impor tidak berkaitan erat dan tidak saling mempengaruhi berdasarkan kurun waktu penelitian ini karena tidak memiliki hubungan sebab akibat. Inflasi periode yang lalu tidak mempengaruhi secara signifikan terhadap impor Indonesia. Inflasi dan impor tidak memiliki pengaruh langsung karena secara teori, inflasi dan jumlah uang beredarlah yang memiliki pengaruh langsung dan kemudian berdampak pada impor dalam negeri.

Peningkatan impor berpengaruh positif terhadap inflasi berdasarkan persamaan VAR. Dan antara inflasi dan impor terdapat hubungan stabilitas keseimbangan jangka panjang dan pergerakan dalam jangka panjang. Sementara dalam jangka pendek kedua variabel inflasi dan impor saling menyesuaikan untuk mencapai keseimbangan jangka panjang.

\section{DAFTAR PUSTAKA}

Bank Dunia. 2018. Data Inflasi dan Impor Indonesia. dari https://www.worldbank.org/ (diakses pada tanggal 12 Nopember 2018).

Basuki, Agus Tri dan Prawoto, Nano. 2016. Analisis Regresi dalam Penelitian Ekonomi dan Bisnis. Raja Grafindo, Jakarta.

Gujarati, N. Damonar. 2003. Ekonometrika Dasar. Terjemahan. Erlangga, Jakarta.

Hutabarat, R. 1996. Transaksi Ekspor Impor. Erlangga, Jakarta.

Mankiw, N. Gregory. 2003. Teori Makroekonomi Edisi Kelima. Terjemahan. Erlangga. Jakarta.

Nachrowi, Djalal Nachrowi dan Usman, Hardius. 2006. Pendekatan Populer dan Praktis Ekonometrika untuk Analisis Ekonomi dan Keuangan. Universitas Indonesia. Jakarta.

Sembiring, Masta. 2016. Analisis VAR terhadap Interrelationship Antara IPM dan Pertumbuhan Ekonomi di Sumatera Utara. Jurnal Ilmiah. Universitas Muhammadiyah Sumatera Utara. Medan.

Sukirno, Sadono. 2004. Makroekonomi Teori Pengantar Edisi Ketiga. Rajawali Pers, Jakarta. 